\title{
Organ Procurement and Transplantation Network
}

National Cancer Institute

\section{Source}

National Cancer Institute. Organ Procurement and Transplantation Network. NCI

Thesaurus. Code C110970.

The transplant network established by the U.S. Congress under the National Organ

Transplant Act of 1984. It is a public-private partnership, linking all professionals involved in the national donation and transplantation system. 